\title{
Libya's step towards change
}

\author{
Najeb Masoud ${ }^{1,2}$ \\ ${ }^{1}$ Department of Banking and Finance, Al-zaytoonah University Business School \\ ${ }^{2}$ Al-zaytoonah University of Jordan, Box 130, Amman 11733, Jordan
}

\section{Email address:}

najeb2000@gmail.com

\section{To cite this article:}

Najeb Masoud. Libya's Step towards Change. Journal of World Economic Research. Vol. 2, No. 4, 2013, pp. 75-81. doi: 10.11648/j.jwer.20130204.12

\begin{abstract}
This paper has offered a comprehensive analysis of the macro environment of Libya and the performance and evolution of commencing financial sector development in the national economy. Following the 1969 revolution, the economy witnessed three major systems: the nationalism and socialism period, an open door policy period and, latterly, the economic reform programme. The economy experienced rapid expansion during the 1970s and early 1980s as real GDP grew by more than 10 per cent on average. This expansion was mainly financed by the oil revenue sector. In the mid-1980s economic growth slowed and the Libyan government started to experience reversionary trends. These later trends saw the collapse of oil prices and the Gulf war in 1990/1991. Following the collapse of its economy, Libya was forced to reexamine its policies and redirect its development strategies. The challenges of devising a strategic policy aimed at achieving the sustainable development of the Libyan economy are particularly linked to current official tendencies for restructuring the economy through increasing the role of the private sector and by continuing the process of privatising the public sector within the country. That outline, if achieved, would transform life for all Libyan citizens in terms of daily activities and the business environment.
\end{abstract}

Keywords: Libyan Economy, Macro-Economic, Financial Maturity, Investment Policy, Economic Growth

\section{Introduction}

Overall, Libya still has some way to go with its macroeconomic situation such as: a high rate of unemployment, low rate of domestic saving and low ratio of investment to GDP including key governance indicators: regulatory and corruption. Competition law additionally did not exist in the market. The IMF's [1:68] stated it, "welcomed the authorities' increased reform efforts but noted that much needs to be done to transform the country into a market economy [...] In the short run, policies should focus on developing market-based monetary instruments, restructuring the banking system, liberalising prices, strengthening budgetary management and procedures, and reforming the subsidy system [...]A prudent medium-term fiscal framework would help reduce the large non-oil deficit by strengthening the non-oil tax base, including reducing tax exemptions and streaming spending”. The Libyan government should evidently improve all the aforementioned areas for action to provide a healthy business environment and develop economic growth, including data-bank of works. The country's legislation needs to develop too. Further, at the micro-economic level, skills and physical infrastructure require improvement. Customer demand is limited at present.

\section{Establishment of the SSF and ORF for Libya}

The purpose of this section is to discuss the twofold situation of: the establishment of a Stabilisation and Saving Fund (SSF) and the experiment of the Oil Reserve Fund (ORF) in the Libyan economy.

\subsection{The Establishment of the SSF for Libya}

Libya's budget is heavily dependent on oil, which contributed approximately 80 per cent of government revenue during 2000-2005 [2]. Given the volatility of oil prices and difficulty in forecasting the impact on cash flows of public sector finance, there is a strong macro-economic reform case for the Libyan economy to reserve part of this wealth to achieve financial sustainability for the populace in the long-term, besides achieving justice in the distribution of wealth between generations. This could be affected by the establishment of a Stabilisation and Saving 
Fund (SSF). There are many factors that would justify the establishment of SSF in the Libyan economy. These include: the heavy dependence of the budget on volatile oil revenues and, therefore, exposure to the risks of volatility and the limited absorptive capacity in the Libyan economy, plus the desire of authorities to gradually reduce the rate of public sector involvement in the economy, which requires protection from "Dutch Diseases" .

\subsection{Libya's Experience with the ORF}

The ORF established in 1995 to achieve the following objectives: to reduce the impact of oil price fluctuations in the short-term on government expenditure; and to protect the budget from political pressures driving spending when oil revenue is at a higher rate. However, the status of the ORF remains unclear where no regulations were issued, or its operating principles, the agency that controls it include ORF's relations with the budget [2].

The establishment of the ORF in 1995 and the first two years of its existence were outlined in Table 1. During 1992-1994, there was a sharp decline in oil revenues by 12 per cent of GDP, the authorities reduced the non-oil fiscal deficit by more than 3 per cent of GDP, and managed to contain the overall total fiscal deficit at 3 per cent of GDP. In 1995-96 whilst the rate of oil revenues more than doubled in terms of GDP to record 27 per cent of GDP, the non-oil deficit increased to only 2 per cent of GDP.

Table 1. The Main Fiscal Indicators in the Libyan Economy during 19902005

(Per cent of GDP)

\begin{tabular}{lllllll}
\hline Factors & $\mathbf{1 9 9 0 - 9 1}$ & $\mathbf{1 9 9 2 - 9 4}$ & $\mathbf{1 9 9 5 - 9 6}$ & $\mathbf{1 9 9 7 - 9 8}$ & $\mathbf{1 9 9 9 - 0 2}$ & $\mathbf{2 0 0 3 - 0 5}$ \\
\hline Overall fiscal balance of which: & 5.1 & -3.1 & 8.3 & -2.4 & 7.0 & 21.5 \\
Non-oil fiscal deficit & -19.5 & -16.1 & -18.4 & -22.1 & -22.6 & -34.0 \\
ORF expenditure & 0.0 & 0.0 & 0.0 & 1.3 & 5.5 & 9.7 \\
Expenditure/ NOR a (per cent) & 250.2 & 209.1 & 237.1 & 273.5 & 273.6 & 659.8 \\
$\begin{array}{l}\text { Oil price for Libya (US\$ per } \\
\text { barrel) }\end{array}$ & 20.3 & 16.5 & 18.0 & 15.5 & 23.0 & 39.6 \\
Oil revenue & 24.6 & 13.0 & 26.7 & 19.7 & 29.6 & 55.5 \\
\hline
\end{tabular}

Notice: $\mathrm{NOR}=$ Non-oil revenue.

Source: [2].

Additionally, between 1997 and 1998, there was a break in the government's fiscal discipline, which led to increased use of ORF resources to finance discretionary spending outside the budget, such as the average spending of 6 per

\footnotetext{
${ }^{1}$ The Dutch Disease was driven from the difficulties experienced by the Dutch economy as a result of the natural gas discoveries of the 1960 s. Therefore, the Dutch Disease theory is a comparative statistic approach exploring the short to medium-term structural effects of a boom emanating from either a new resource discovery or an increase in the price of an exportable commodity. It also reduces the share of manufacturing in aggregate output through change in the structure of prices. The focuses on the interrelationship between factors mobility, output and predicts that, in an economy structure in full employment equilibrium, a permanent increase in the inflow of external funds will lead to a change in related prices in favour of the non-traded goods sector but against the traded goods sector, which lead to a contraction of employment and output in traded sector. This phenomenon is referred to in the Dutch Disease literature as "De-industrialisation" for more details see [3].
}

cent of GDP during the period 1999-2002, and increased to 10 per cent of GDP in 2003-2005. Although these developments have undermined the goals of achieving stability and long-term savings they have, additionally, raised significant transparency issues, where large amounts of the ORF's resources have been spent outside budget operations, for which there is a paucity of information.

\subsection{Other Financial Institutions}

Other financial institutions include: Libyan Stock Market (LSM); Libyan Social Security Fund (LSSF); Foreign Exchange and Financial Services Company (FEFS) and three public investment companies (National Investment Company; Libyan Arab Africa Investment Company; Libyan Arab Foreign Investment Company). In addition, there is one public company: Libyan Insurance Company (LIC), which included three private insurance companies: Africa Insurance Company (AIC); United Insurance Company (UIC) and Sahara Insurance Company (SIC).

\section{Financial Maturity}

The success of any nation's financial sector in any country depends firstly upon whether the country has made progress in the economy, banking flexibility and the country's currency policy effectiveness. As the government takes responsibility for economic improvement, the increasing number of corporate companies in the banking sector becomes stronger, controls inflation as the financial market activates and achieves the required goals. Furthermore, the tendency to purchase bonds increases in the market. Although the financial sector is relatively modern compared with other financial markets, it surpasses other financial institutions whether in its organisation or decisions and facilities for dealers due to the huge degree of investment which is handled in these markets. The economic role increases for such markets and is encapsulated in the activities of stock exchanges which can be found worldwide.

As illustrated in Figure 1, these three characteristics investigated a variable which was not considered in any of the financial maturity research. The aim of the latter, according to Centre for European Policy Studies [4,5] and King and Levine [6,7] is related to the financial sector which is crucial for capital allocation, financial intermediation (i.e. banking sectors) and conversion of savings into investments.

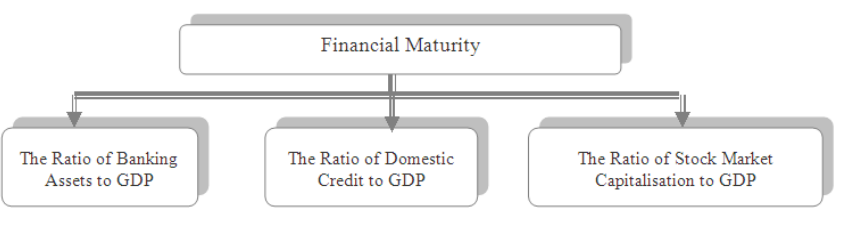

Source: Author, 2013.

Figure 1. Potential Financial Maturities

Figure 2 display how financial sector measures are 
relatively important to GDP ratio. Firstly, the ratio of banking assets to GDP confirms that the levels of financial intermediation are comparatively low. The banking sectors currently remain small in terms of the economic activity generated. But the ratio of banking assets to GDP ratio is not always sound evidence for banking system fit ${ }^{2}$.

The result found that the total ratio of banking assets to GDP increased from 12.41 per cent in 1970 and continued to rise to reach 75.10 per cent in 1986 . However, this ratio reduced from 68.91 per cent in 1987 to 48.70 in 2003. Secondly, domestic credit provided by the banking sector includes all credit to various sectors with the exception of credit to central government. The ratio of domestic credit to GDP ratio increased from 7.46 per cent in 1970 to 30.89 in 1986, then subsequently decreased to about 21.35 in 2003. The low share of domestic credit in GDP ratio could, in fact, illustrate the limited level of banking intermediation in a developing country. Finally, the measures partially address concerns about stock market capitalization, ${ }^{3}$ which increased from 0.17 per cent in 1970 to 23.07 per cent in 1986. This, though, had reduced to 4.35 per cent at the end of 2003. This result is extremely low due to the complete absence of a capital market during this period.

\section{Investment Policy in the Libyan Economy}

The trends of investment policy in the Libyan economy were considered a variable, dependant on the size of oil revenue contribution to the general budget. In circumstances where oil revenues were booming, production investment policies were adopted, and there was commitment to implementing developmental plans besides subsidising the essential product sectors. This was achieved between the years 1975 to 1985 . Clearly, due to declining oil revenues, constrained investment policies were later implemented. These focused on rationalisation of public expenditure and meeting essential consumption needs, especially in public service activities. Accordingly, these latter benefited from a major percentage in the allocation of investments.

\subsection{Dominance of the Public Sector in Local Investments}

The National Authority [9] explained that investments were distributed between the public and private sector during 1973-1990 as appears below:

1. The public sector dominated 86 per cent of investments during 1973-1990, while the private sector's share was only 14 per cent.

2. The public sector's share of total investments in the agricultural sphere reached around 93.7 per cent,

\footnotetext{
${ }^{2}$ See further details [8].

${ }^{3}$ In this context, i.e. Libya, there was only a primary market available at that interval, as it had no secondary capital market until June 2006. Stock market capitalisation was measured by Jamahiriya Treasury Bills and Securities.
}

with only 6.3 per cent in the private sector.

3. In the industrial arena, the public sector's share reached 19.2 per cent, while the private sector's share was merely 2.3 per cent.

4. Investment in the transportation sector was approximately 18.9 per cent of total economic investments; it was 15.3 per cent in the public sector and only 3.06 per cent in the private sector.

5. Investment in the housing sector was 15.2 per cent of total economic investment, where the public sector's share was 9.7 per cent and the private sector's share was 5.5 per cent.

6. Only 0.1 per cent of investment was devoted to financial, insurance and business services, all of which were granted to the public sector.

As for the distribution of local investments between the public and private sector, Table 2 demonstrates the distribution of investments among these sectors during 1970-2002. It is notable that most investments made in various economic sectors were enacted by the public sector. Here, investments reached 547 million LYD, representing 69 per cent of total investments between 1970-1972, increasing to 7,283 million LYD, representing 87.2 per cent of total investments during 1976-1980, then decreasing to 3,296 million LYD, representing 75.4 per cent during 19911997. This increased again to 4,696 LYD, representing 85 per cent for 2001-2002. Investments in the private sector increased to 2,444 million LYD representing 31 per cent during 1970-1972, and increased to 1,075 million LYD, representing 25 per cent during 1991-1997 and subsequently decreased to 828 million LYD, representing 15 per cent for 2001-2002.

Table 2. Investment Distribution between the Public and Private Sectors 1970-2002

\begin{tabular}{lllllll}
\hline $\begin{array}{l}\text { Sector } \\
\text { Period }\end{array}$ & Public & \multicolumn{3}{c}{ Private } & \multicolumn{3}{c}{ Total } \\
& Value & Per cent Value & \multicolumn{2}{c}{ Percent } & Value & Per cent \\
\hline $1970-1972$ & 5,466 & 69.1 & 2,444 & 30.9 & 7,910 & 100 \\
$1973-1975$ & 17,426 & 79.1 & 4,604 & 20.9 & 22,030 & 100 \\
$1976-1980$ & 72,828 & 87.2 & 10,572 & 12.8 & 82,592 & 100 \\
$1981-1985$ & 9,805 & 91.7 & 887 & 8.3 & 106,920 & 100 \\
$1986-1990$ & 45,012 & 90.2 & 4,401 & 9.8 & 44,913 & 100 \\
$1991-1997$ & 32,957 & 75.4 & 10,753 & 24.6 & 43,710 & 100 \\
$1998-2000$ & 43,638 & 83.7 & 85,00 & 16.3 & 52,138 & 100 \\
$2001-2002$ & 46,960 & 85.0 & 828.0 & 15.0 & 55,240 & 100 \\
\hline
\end{tabular}

Source: $[10,11]$.

\subsection{Foreign Direct Investment in the Libyan Economy}

Since 1997, the Libyan government has actively sought and encouraged an increase in foreign private investments. Law no. 5 for 1997 and its amendment in 2003 by Law no.7, which offered many incentives and numerous guarantees to attract foreign business to participate in realising economic development in Libya, created a new website www.investinLibya.com. The aims of this law, specified by 
article one, included: transfer of modern technology to expand the Libyan technical system; diversification of income sources; contribution to development of national products for international markets. Table 3 illustrates the distribution of Foreign Direct Investment (FDI) among the various economic activities. In 2000 the total FDI in Libya reached 189,150 million LYD and then declined to 121,323 million LYD in 2002. In 2005 it had reached 521,333 million LYD, with an annual growth rate of 143.9 per cent from 2000 to 2005. As for the distribution of these investments among the various non- oil sectors, the following facts can be depicted:

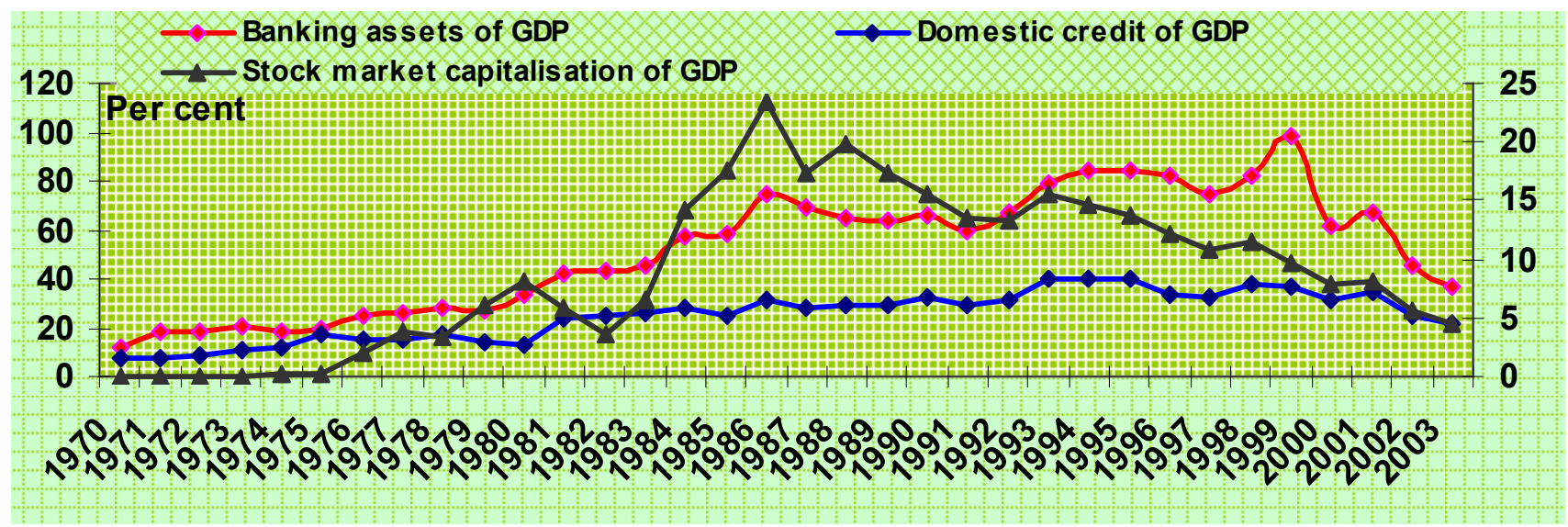

Source: $[12,13,14,15]$.

Figure 2. Financial Maturities in Libya 1970-2003

- The industrial sector occupies first place in attracting FDI. In 2000, 65 million LYD was invested in this sector, which comprised 34.4 per cent of total direct foreign investment. This figure rose to 73,636 million LYD or 60.7 per cent of total investment in 2002 and, finally, amounted to 399,136 million LYD or 76.6 per cent by 2005 .

- The tourism sector ranks second in attracting FDI. In 2000 total incoming investment for this sector was 124,150 million LYD. In other words this represented 65.6 per cent of total FDI that year. By 2003 incoming investment decreased to 112,498 million LYD, the equivalent of 60.3 per cent of total FDI.

- In third position for attracting FDI is the health sector. Investment here reached 29,636 million LYD, or 24.4 per cent of total FDI in 2000 and rose to 65,600 million LYD, or 12.65 per cent in 2005.

- $\quad$ FDI in the service sector reached 17,401 million LYD, or 14.4 per cent of total FDI and increased to 51,872 million LYD, or 9.9 per cent of total investment in 2005.

- $\quad$ FDI in the agricultural sector was 65 million LYD in 2002, which was equivalent to 0.5 per cent of that year's total FDI. By 2005 this figure rose to 4,725 million LYD, or 0.9 per cent of total FDI.

Table 3. Development in the Size of FDI in Economic Sectors 2000-2005

(Million LYD)

\begin{tabular}{|c|c|c|c|c|c|c|c|c|c|c|c|}
\hline \multirow{2}{*}{$\begin{array}{l}\text { Sectors } \\
\text { Years }\end{array}$} & \multicolumn{2}{|l|}{ Industrial } & \multicolumn{2}{|c|}{ Agricultural } & \multicolumn{2}{|l|}{ Tourism } & \multicolumn{2}{|l|}{ Health } & \multicolumn{2}{|l|}{ Service } & \multirow{2}{*}{$\begin{array}{l}\text { Total } \\
\text { Value }\end{array}$} \\
\hline & Value & $\%$ & Value & $\%$ & Value & $\%$ & Value & $\%$ & Value & $\%$ & \\
\hline 2000 & 65,000 & 34.4 & NA & NA & 124,125 & 65.6 & NA & NA & NA & NA & $189,125.0$ \\
\hline 2001 & 14,763 & 100 & NA & NA & NA & NA & NA & NA & NA & NA & 14,763 \\
\hline 2002 & 73,636 & 60.7 & 0,650 & 0.5 & NA & NA & 29,636 & 24.4 & 17,401 & 14.4 & $121,323.0$ \\
\hline 2003 & 33,979 & 18.2 & NA & NA & 112,498 & 60.3 & 30,175 & 16.2 & 3,557 & 3.3 & $108,209.0$ \\
\hline 2004 & 155,047 & 83.4 & 4,960 & 2.7 & NA & NA & 10,556 & 5.7 & 15,190 & 8.2 & $185,753.0$ \\
\hline 2005 & 399,136 & 76.6 & 4,725 & 0.9 & NA & NA & 65,600 & 12.6 & 51,872 & 9.9 & $521,333.0$ \\
\hline
\end{tabular}

Source: [16].

Finally, the size of FDI is still limited for the various economic sectors. This is related to the investment environment that is constricted by the burdens of administrative organisation and bureaucracy; where privatisation is very slowly progressing and the infrastructure is inadequate. This is in addition to the fact that the local market has yet to develop appropriately. In addition, the most significant of these nations seems to score well on financial development indictors. [17] argue that is likely to be positively correlated with per-capita income growth. On the other hand, FDI is a smaller extent with financial development indictors on a bank-based system in particular. 


\subsection{Geographical Distribution of FDI}

The total of incoming FDI industry to the Libyan economy reached 4,729,618 million LYD in the period 2000 to 2005, as Table 4 shows, wherein thirty countries have directly invested in Libya, nine of these being Arab. The following can be depicted:

1. The UK ranks as first, where its investments reached 2,757,729 million LYD, or 58.3 per cent of total FDI from 2000 to 2005.

2. Mauritius lies in second position. Its investment reached 650,000 million LYD, or 13.74 per cent of the total FDI during the period 2000-2005.
3. Third position is occupied by the UAE, which ranks as number one among Arab countries directly investing in Libya. UAE investment reached 311,461 million LYD, equivalent to 6.5 per cent of total FDI from 2000 to 2005.

4. Algeria rates fourth in position, and second among Arab countries directly investing in Libya. It has invested 260,427 million LYD, or 5.51 per cent of total FDI in the period between 2000 and 2005.

5. The total investment of Arab countries in the Libyan economy reached 843,992 million LYD, which is 17.8 per cent of total FDI during the period 2000-2005.

Table 4. Geographical Distribution of FDI in Libya According to Nations 2000-2005

(Million LYD)

\begin{tabular}{|c|c|c|c|c|c|c|c|}
\hline Rank & Nation & Total FDI & $\begin{array}{l}\text { Co-operation } \\
\text { Ratio (per cent) }\end{array}$ & Rank & Nation & Total FDI & $\begin{array}{c}\text { Co-operation } \\
\text { Ratio } \\
\text { (per cent) } \\
\end{array}$ \\
\hline 1 & Saudi Arabia & 4,900 & 0.10 & 16 & Belgium & 4,297 & 0.09 \\
\hline 2 & Bahrain & 7,800 & 0.16 & 17 & Turkey & 4,286 & 0.09 \\
\hline 3 & UAE & 311,461 & 6.50 & 18 & Russia & 9,945 & 0.21 \\
\hline 4 & Palestine & 4,076 & 0.08 & 19 & Slovakia & 0,629 & 0.01 \\
\hline 5 & Jordan & 19,088 & 0.40 & 20 & Switzerland & 22,541 & 0.48 \\
\hline 6 & Morocco & 6,582 & 0.14 & 21 & France & 14,955 & 0.32 \\
\hline 7 & Tunisia & 105,976 & 2.24 & 22 & Cyprus & 43,358 & 0.92 \\
\hline 8 & Egypt & 123,682 & 2.61 & 23 & Canada & 2,499 & 0.05 \\
\hline 9 & Algeria & 260,427 & 5.51 & 24 & Korea & 19,500 & 0.41 \\
\hline 10 & Bosnia & 3,864 & 0.08 & 25 & Malta & 170,530 & 3.60 \\
\hline 11 & China & 6,662 & 0.14 & 26 & Mauritius & 650,000 & 13.74 \\
\hline 12 & Germany & 13,064 & 0.27 & 27 & Holland & 3,712 & 0.08 \\
\hline 13 & Sweden & 2,232 & 0.05 & 28 & Spain & 6,773 & 0.14 \\
\hline 14 & Greece & 1,424 & 0.03 & 29 & UK & $22,757,729$ & 58.30 \\
\hline 15 & US & 50,585 & 1.07 & 30 & Italy & 97,041 & 2.05 \\
\hline \multicolumn{3}{|c|}{ Total } & & & & $4,729,618$ & \\
\hline
\end{tabular}

Source: [16].

\subsection{FDI Performance and FDI Potential}

The previous section discussed the inflow of FDI to Libya, and the distribution of these investments among various economic sectors. For the reasons already noted, these inflows do not express economic performance in attracting direct foreign investment, therefore it is necessary to define Libya's ranking in the indicators of $F D I$ Performance and FDI Potentials, which are issued by the $\mathrm{UNCTAD}^{4}$. Libya, however, is one of 16 Arab countries

4 The indicator of a country's performance in attracting FDI Performance measures the status quo of the country with regards to its actual share in the flow of incoming direct foreign investment internationally attributed to the country's shares of world GDP. This calculates the average of three included in the FDI Performance and FDI Potential, from a total of 140 countries worldwide; ranking is according to position in both indices and to the most recent period of time available in comparison to previous periods (Table 5).

years in order to limit the effect of seasonal factors. FDI Potential measures future ability of the country to attract FDI using 13 components, including rate of GDP growth, average income per individual, ratio of exports to GDP, abundance of mobile and fixed phone lines, average energy consumption per individual, the ratio of expenditure on research and development to GDP, ratio of post graduate students to total population, sovereign classification of the country, the country's share of the world's natural resources, ratio of importing spare parts for electronic devices and cars to the world, ratio of the country's export of services to the world and, finally, the country's share in the cumulative account of FDI worldwide [18]. 
Table 5. Distribution of FDI Performance and Potential 1999-2002

\begin{tabular}{llllll}
\hline \multicolumn{2}{l}{ FDI Performance Index } & \multicolumn{4}{l}{ FDI Potential Index } \\
Country & $\mathbf{1 9 9 9 -}$ & $\mathbf{2 0 0 0}$ & & $\mathbf{2 0 0 0 -}$ & $\mathbf{2 0 0 1 -}$ \\
& $\mathbf{2 0 0 1}$ & $\mathbf{2 0 0 2}$ & Country & $\mathbf{2 0 0 2}$ & $\mathbf{2 0 0 3}$ \\
\hline Qatar & 13 & 8 & Sudan & 84 & 29 \\
UAE & 19 & 17 & Morocco & 62 & 32 \\
Kuwait & 32 & 28 & Bahrain & 72 & 51 \\
Bahrain & 31 & 29 & Tunisia & 60 & 58 \\
Saudi Arabia & 28 & 31 & Qatar & 81 & 67 \\
Jordan & 41 & 45 & Jordan & 57 & 84 \\
Libya & 39 & 46 & Lebanon & 96 & 90 \\
Oman & 50 & 53 & Algeria & 94 & 91 \\
Lebanon & 57 & 60 & UAE & 120 & 101 \\
Egypt & 71 & 70 & Libya & 137 & 116 \\
Tunisia & 74 & 71 & Syria & 114 & 121 \\
Algeria & 79 & 75 & Egypt & 113 & 123 \\
Yemen & 85 & 87 & Yemen & 115 & 124 \\
Morocco & 96 & 93 & Oman & 130 & 126 \\
Syria & 93 & 100 & Kuwait & 136 & 137 \\
Sudan & 124 & 120 & Saudi Arabia & 138 & 138 \\
\hline
\end{tabular}

Source: [18].

Qatar, UAE and Kuwait occupied the first three positions in FDI Performance in relation to Arab countries, whereas Libya occupied $7^{\text {th }}$ position. Sudan, Morocco and Bahrain occupied the first three positions in the FDI Potential relating to Arab nations, whilst Libya occupied $10^{\text {th }}$ place. In addition, Table 5 illustrate that from 140 nations worldwide, Libya occupies $39^{\text {th }}$ position as regards FDI Performance for attracting FDI, while it occupies $116^{\text {th }}$ position in the FDI Potential for attracting FDI. This indicates that the country attracts a relatively small flow of FDI in comparison to its Potential, which means that it has unexploited Potential for attracting FDI.

According to the previous analysis, it is observed that the size of FDI in the Libyan economy is below expectations. It is further noted that most of this was in the oil and gas sectors, in which investment allows the utilisation of local resources in other investments, while the Libyan economy requires investment and partnerships in other sectors with renewable resources that permit launch of the production operation in all sectors. Insufficient direct foreign investment in the Libyan economy may be justified by the following:

- The absence of competing markets, as the Libyan market has undergone business to achieve the required reforms. However, this is relatively acceptable taking into consideration the economic embargo that Libya suffered during its economic crises, besides the absence of financial markets linked to the wider international market by means of information networks that can increase financial flow to the investment operation.

- In addition, FDI are closely related to the extent by which the private sector is able to contribute to the productive operation. Unfortunately, this sector has not achieved the desired level, and most investments in the various economic sectors have been enacted by the public sector, where the ratio of its investment has reached 88 per cent of total investments. Contrastingly, private sector participation did not exceed 12 per cent in the period 1970-1997 (The Libyan Revolution in 30 Years). Moreover, the private sector is unable to perform its required role due to the lack of skill and experience, whereas in other countries this sector is relied upon to attract foreign investment through utlising its experience and special relationships with foreign investors.

\section{Summary and Conclusion}

The challenges of devising a strategic policy aimed at achieving the sustainable development of the Libyan economy are particularly linked to current official tendencies for restructuring the economy through increasing the role of the private sector and by continuing the process of privatising the public sector within the country. That outline, if achieved, would transform life for all Libyan citizens in terms of daily activities and the business environment. There are seven-fold main points of this research that can define this vision:

1. Libya occupies an extremely large land area, has a safe environment, has friendly people protecting its history and heritage, its long-term future investing and home to leading in desert art, culture and music and tourist destination, which gives lend advantages that will allow the country to compete upon the international stage.

2. The Libyan economic reform programme was inaugurated during 1999 resulting from many factors such as: economic crisis in terms of oil price collapse by the mid-1980s and the early 1990s; international UN sanctions following US Libyaspecific trade sanctions in the early 1990s.

3. Most macro-economic reform variables (exchange rate, interest rate, inflation rate, budget deficit, balance of payment, per-capita income and GDP growth rate), which improved positively, especially, after adopting economic reform in 1999.

4. Since implementing its economic reform programme Libya's wealth has grown strongly amongst the country's small population due to oil price increases. Economic development has two significant factors: a high value/ low employment energy sector and a low value/ high employment non-energy sector. The latter contributes about 40 per cent of GDP employing 97 per cent of the formal workforce ranked at a very low level of productivity. Oil revenues accounted for about 9095 per cent of exports and over 60 per cent of total GDP with employment of about 3 per cent of the population. The size of the informal economy is 
estimated at 30-40 per cent of GDP. Additionally, the fiscal and external current account balance reached large surpluses of about 14.5 and $35.0 \mathrm{per}$ cent of GDP during 2004 and 2005 respectively, which provided a sound opportunity to accelerate economic reform. Moreover, international revenues rose sharply in this interval.

5. Libya's physical infrastructure quality in many areas (i.e. network information and communication technology, airports, ports, roads-it still has no railway system) is significant when compared with regional standards of other MENA countries. During the 2005-2008 period the Libyan government is expected to spend 100 billion LYD upon infrastructure, including 450,000 homes, hospitals, educational facilities and a railway system.

6. The Libyan education system has two strategic goals which are: to contribute to social, economic and cultural development by improving human skills and abilities; and to rapidly ameliorate living standards for development of the society as a whole

7. FDI, as mentioned in earlier discussion, brings to the country an inflow of new technology, training and skills, business techniques and access to new export markets, for instance: Dubai, Malaysia, and Singapore. Libya, however, ranks poorly in terms of FDI promotion; its FDI performance ranked as $46^{\text {th }}$ among leading countries during 2000/02, but during 2001/03 FDI potential was not even among the top 116 nations internationally.

JEL Classifications: G0; G10; G15; G18; G19

\section{References}

[1] IMF International Monetary Fund (2005). International Monetary Fund Country Report No.05/83, Washington D.C. March.

[2] IMF International Monetary Fund (2006). Socialist People's Libyan Arab Jamahiriya Country Economic Report, World Bank Report, (30295-LY).

[3] Karshenas, M. (1994). Structural adjustment and Employment in the Middle East and North Affric", Economic Research Forum Working Paper (9420), Cairo.
[4] CEPS Centre for European Policy Studies (2005). From Barcelona process to neighborhood policy assessments and open issue Michael Emerson and Gergana Noutcheva, CEPS Working Document, (220) March, pp.1-23.

[5] Levine, R. (1997). Financial development and economic growth: views and agenda, Journal of Economic Literature, 35(2), pp.688-726.

[6] King, R.G. and Levine, R. (1993a). Financial, entrepreneurship and growth: theory and evidence, Journal of Monetary Economics, 32(3), pp.513-542.

[7] King, R.G. and Levine, R. (1993b). Finance and growth: Schumpeter might be right, Quarterly Journal of Economics and Statistics, 3(3), pp.717-737.

[8] Mackenzie, M., Gray, A., Bullock, N. and Gangahar, A. (2008). US stocks plummet to 3-Year lows [online] Available at: <http:www.ft.com $/ \mathrm{cms} / \mathrm{s} / 0 / 7861 \mathrm{c} 050>$ [Accessed $16^{\text {th }}$ July 2013).

[9] NARS National Authority for Research Science. (1992). General principles for restructuring the Libyan economy, Summer, Unpublished Study, p. 14.

[10] Libyan Arab Jamahiriya, Libya's Revolution 30 years. (2000). Political and economic transformations 1969-1999. $2^{\text {nd }}$ ed. Republic House for Publication and Distribution, Widely, p.255, (in Arabic).

[11] CBL Central Bank of Libya. (2004). Research and statistics, economic bulletin, $48^{\text {th }}$ annual report, Tripoli, Libya.

[12] CBL Central Bank of Libya. (1966-2000). Research and statistics, economic bulletin, money and statistics.

[13] CBL Central Bank of Libya. (2006). Fiftieth annual report.

[14] CBL Central Bank of Libya. (2007). Research and statistics, economic bulletin, $51^{\text {st }}$ annual report, Tripoli, Libya.

[15] CBL Central Bank of Libya. (2008). Economic bulletin for the $1^{\text {st }}$ quarter of the year 2008 .

[16] IEA Investment Enhancement Agency, Annual Reports. (2000-2005).

[17] Omran, M. and Bolbol, A. (2003). Foreign direct investment, financial development, and economic growth: evidence from the Arab countries," REV. Middle East Economic Finance, 1 (3), pp.231-249.

[18] AOGI Arab Organization for Guarantee of Investment. (2004). Investment climate in Arab countries. 